The $B D J$ News section accepts items that include general news, latest research and diary events that interest our readers. Press releases or articles may be edited, and should include a colour photograph if possible. Please direct your correspondence to the News Editor, Arveen Bajaj at the BDJ, The Macmillan Building, 4 Crinan Street, London N1 9XW or by email to bdj@bda.org

\section{Last candidate completes Diploma}

Dr Surinder Bhatti of Slade Dental Practice in London has become the last candidate to successfully obtain the Diploma of Membership in General Dental Surgery (MGDS) from the Royal College of Surgeons of England and at 31 years of age, also happens to be youngest in its history.

The MGDS exam has been running from 1979 and is being discontinued at the England College. However the Glasgow and Ireland Colleges will continue to offer the exam. In the UK there are fewer than five hundred holders of this diploma.

The MGDS has now been incorporated within the FGDP(UK) Career Pathway in dentistry, which provides a career development framework for the primary dental care practitioner, ultimately leading to the Fellowship of the Faculty of General Dental Practice (UK)

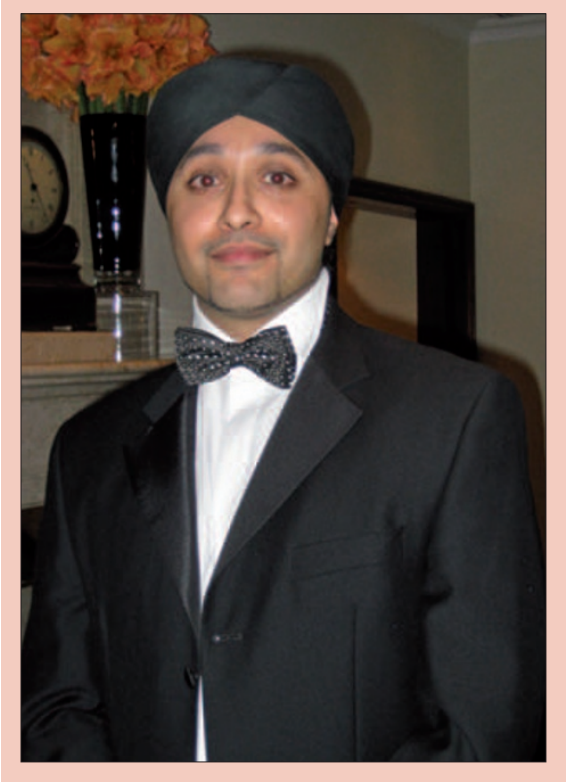

\section{ADA Honour for BDJ Editor-in-Chief}

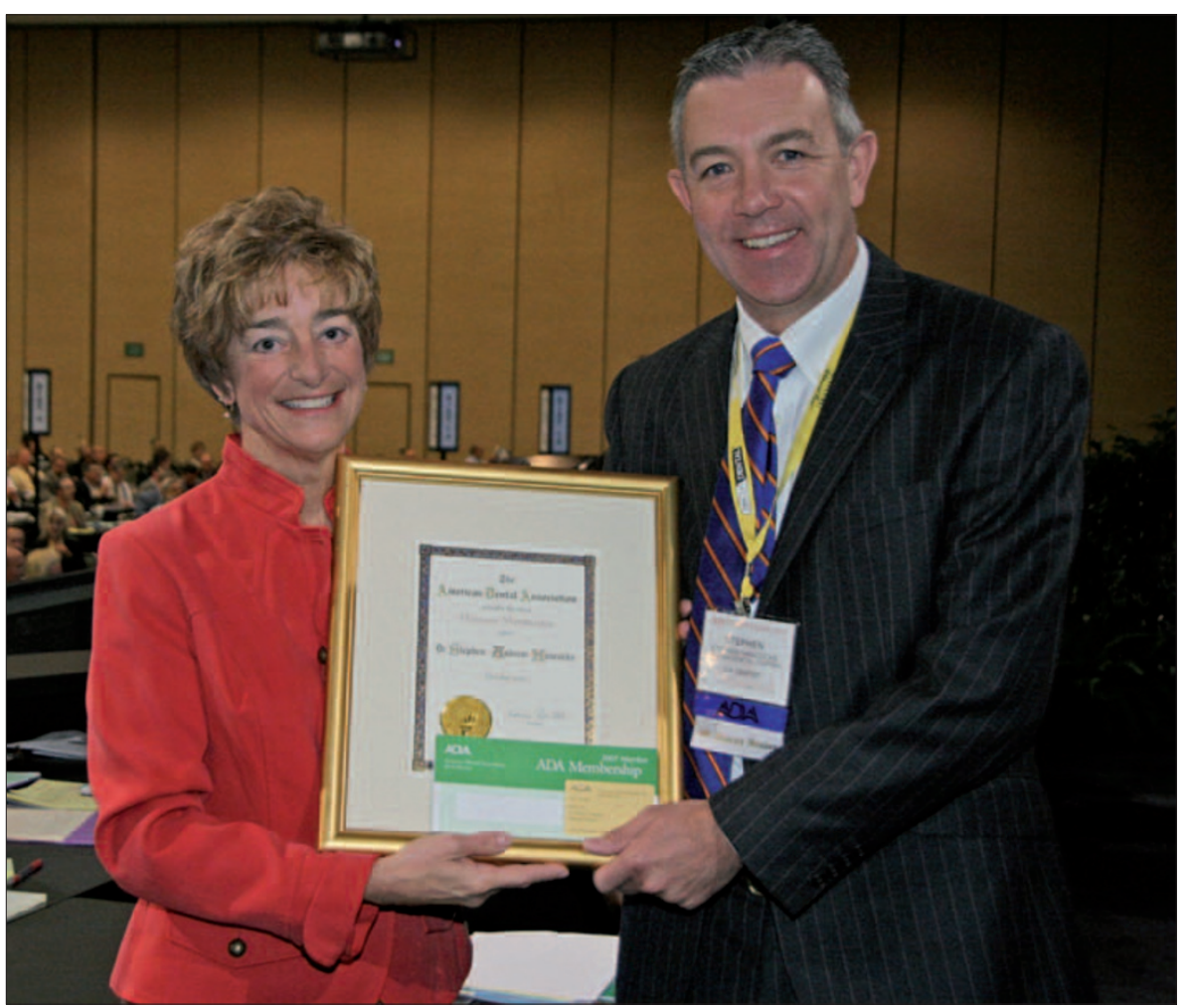

The American Dental Association (ADA) has bestowed Honorary Membership on Stephen Hancocks, Editor-in-Chief of the British Dental Journal and Editor of the FDI's International Dental Journal. The honour, awarded to only a handful of people worldwide in any given year, was presented to Stephen at the ADA's recent annual convention in San Francisco.

ADA President Kathy Roth said that she was personally and professionally delighted that the nomination had come during her time as President and said it reflected Stephen's major contribution to writing, editing and publishing dentistry around the world. Stephen responded by thanking not only the ADA for its friendship and regard in giving this honour but also the teams at the BDA/J and the FDI, and his partner without whom none of the achievements would have been possible.

The $B D J$ had a major presence at the ADA meeting together with the full range of $B D J$ Books and the other BDA-Nature publications at its booth in the huge world dental showcase exhibition. Attracting an attendance of over 47,000 over four days, the Convention enabled the $B D J$ to meet many of its overseas readers face-to-face. A high percentage of unique visitors to the journal's growing website come from North America and results of a questionnaire conducted to discover their views on the content will be fed back into the editorial process.

Meetings between the editorial and publishing team members of the $B D J$ and JADA also paved the way for continuing and increasing co-operation between the two journals, which together provide major coverage of the world's dental readership. Pictured above, ADA President Kathy Roth presents Stephen with the Association's Honorary Membership. 


\section{'Apprentice' winner to speak at Young Dentist Conference}

This year's Young Dentist Conference will see a programme of renowned speakers present to an audience of young dentists. This will include Tim Campbell, winner of the first series of the BBC's television programme 'The Apprentice'.

Building on the success of the 2007 Young Dentist Conference, the BDJ, BDA

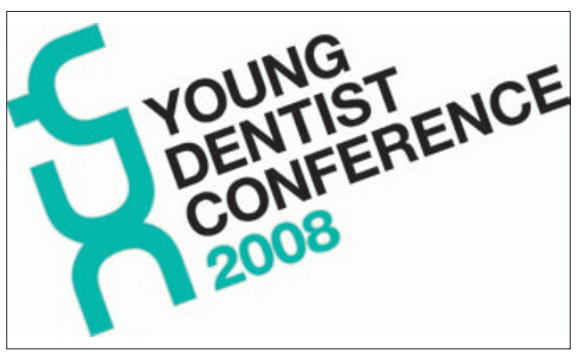

and Dental Protection have again joined forces to present a one-day programme directed specifically to the needs of young dentists, featuring speakers from both dentistry and business backgrounds.

As in previous years, the conference will deliver challenging ideas, facts and practical tips with an emphasis on how various issues impact upon young dentists in the early years of their careers.

Highlights include Surgery 101 - Who Owns Dentistry, The Anatomy of the Entrepreneur and Class of 2002 - For Better or Worse. The Young Dentist Conference will be staged at the Royal College of Physicians in London on 9 February 2008, and tickets are now on sale. Visit www.dentalprotection.org for further information.

\section{Death notice}

We are sorry to report the recent deaths of Christopher Hogg, who died unexpectedly at his home in Mansfield, and of Professor Neil Jenkins, aged 92 .

\section{Correction}

In $B D J$ volume 203 number 7 , on p382 we incorrectly reported that Patricia Reynolds from King's College London and Richard Oliver from Cardiff University received chairs in dental education from the Association for Dental Education in Europe.

The chairs were actually given by Kings College London and Cardiff University, respectively.

\section{New consultant in dental public health}

Mr Albert Yeung has been appointed as Consultant in Dental Public Health at NHS Lanarkshire from 1 October 2007, replacing Miss Margie Taylor who took up the post of Chief Dental Officer for Scotland in May 2007.

Mr Yeung has a diverse background of dentistry work experience in the UK, including general dental practice, hospitals, community dental service and teaching in dental schools. Before joining NHS Lanarkshire, he worked for five years as Clinical Lecturer in Dental Public Health at The University of Manchester.

Born in Hong Kong, Mr Yeung came to the UK to study dentistry and graduated from Glasgow University in 1989.
He gained a MMedSci in Paediatric Dentistry at Sheffield University in 1999 and a Masters degree in Public Health at Manchester University in 2004.

He is a Fellow in dental public health of both the Royal College of Surgeons in Ireland and the Royal College of Physicians and Surgeons of Glasgow, a Fellow of the Faculty of Public Health of the Royal Colleges of Physicians of the United Kingdom and a Fellow of The Higher Education Academy. Mr Yeung also holds the post of examiner of the Royal College of Surgeons of England, the Royal College of Physicians and Surgeons of Glasgow, and of the Overseas Registration Examination.

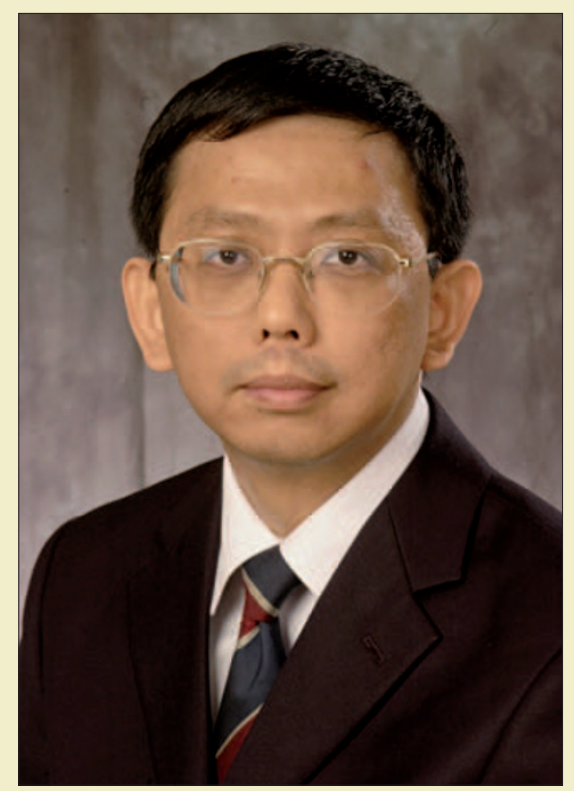

\section{Beneficial bacteria for periodontitis treatment studied}

The application of beneficial bacteria as an adjunct to traditional therapy may become a valid, non-antibiotic treatment approach for periodontitis according to a small-scale animal study.

Researchers applied a mixture of beneficial bacteria after scaling and root planing, a concept called Guided Pocket Recolonisation (GPR). Analysis of the data showed that when beneficial bacteria were applied in periodontal pockets adjunctively after root planing, repopulation by bacteria associated with gum disease was delayed and reduced, as was the degree of inflammation, at a clinically significant level.

With the emergence of antibiotic resistance and the lack of non-antibiotic treatment options, the researchers suggest the GPR approach may provide a valuable addition or alternative to treatment options for periodontitis.

Wim Teughels, corresponding author and Professor in the Department of Periodontology at the Catholic University Leuven, Netherlands commented, 'While this investigation provides a proof of concept that the application of beneficial bacteria may supplement traditional methods of periodontal therapy, additional studies are needed to determine how this concept can be applied in the clinical practice of periodontology.'

He added that the team behind the project are continuing investigations with a focus on testing beneficial bacteria that are both helpful and non-pathogenic to humans.

The study was published in The Journal of Dental Research 2007; 86:1078-1082. 


\section{North West gets new dental school to combat shortage}

A new dental school has opened at the University of Central Lancashire (UCLan). Costing £5.25 million, it will incorporate a range of state-of-the-art technologies, including a phantom head room, where students will carry out practical techniques on manikin heads and a prosthetics laboratory where they will learn to make dental appliances such as crowns and dentures.

Professor Lawrence Mair, Head of school, believes the opening is a step forward in tackling the much debated dentist shortage in the UK. The school is the result of work undertaken by the Cumbria and Lancashire Medical and Dental Education Consortium, a joint venture between UCLan and the Universities of Liverpool, Lancaster and Cumbria.

Together with the NW Strategic Health Authority and local PCT Trusts, they responded to Government figures identifying the chronic need for more qualified dentists in the North West and were awarded funding from the Higher Education Funding Council to train an additional 32 students per year in the North West. Liverpool University have provided the curriculum and UCLan will be responsible for its delivery, supported by Liverpool and Consortium members.

The new four-year graduate entry course offers a balance of theoretical study and practical training, and will provide a new core of qualified dentists across the region. Students will spend their first year studying on campus in the new school at the University of Central Lancashire, before relocating for three years' clinical training at one of four newly-established Dental Education Centres (DECs) in Accrington, Blackpool, Carlisle and Morecambe Bay.

The DECs will be clinical training centres where students will treat patients, under supervision, and gain first-hand experience within the communities they are most likely to serve after graduation.

Professor Mair said, 'This new school is very different from the established schools, in that we have four clinical education centres distributed around the North West rather than being confined to one location, which will allow our students to gain experience in the local communities. Four years may seem a long time before these first cohorts qualify but, even while they are training, they will be providing treatment in the local areas.'

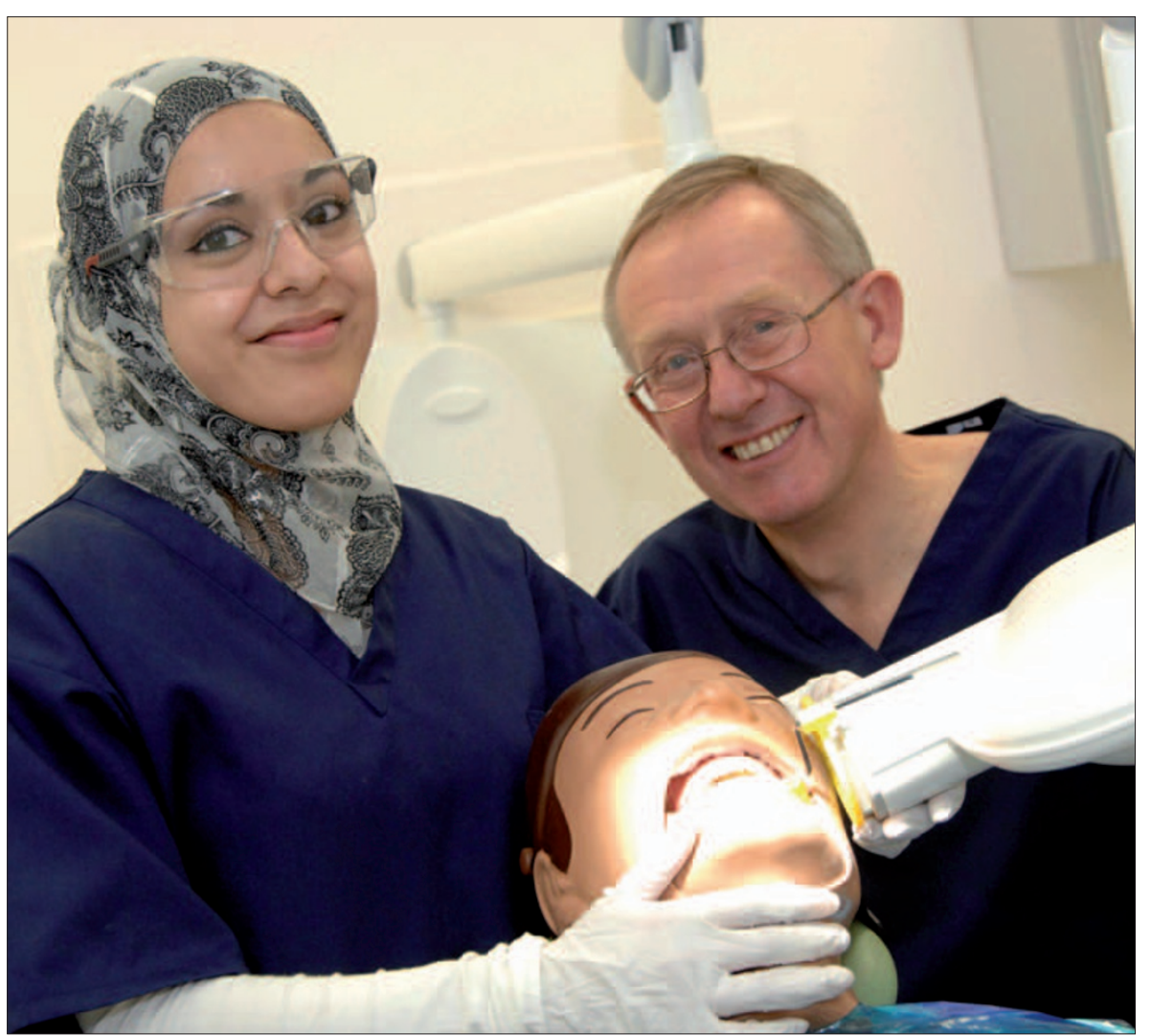




\section{DIARY}

December

Seventh Annual Premier Symposium

Date: 1 December 2007

Venue: Kings College,

London Waterloo campus

Email: sarah.cunliffe@mps.org.uk

www.dentalprotection.org

BDA Bromley and Beckenham Section - Tapping into your unconscious now! Date: 4 December 2007

Venue: Chislehurst Golf Club, Chislehurst Tel: 02084621165

www.bda.org/events

BDA Kingston Section -

Oral and Maxillo-facial war surgery

Date: 4 December 2007

Venue: Malden Golf Club, Surrey

Tel: 02088766090

Email:whitebds@googlemail.com

www.bda.org/events

3rd International Vienna Orthodontic Symposium (IVOS)

Date: 7-8 December 2007

Venue: Vienna, Austria

Tel: (+43/1) 588 00-514

Email:strobl@ivos2007.at

www.ivos2007.at

International Master Course on Implantology

Date: 14-15 December 2007

Venue: Paris, France

www.euromedicom.com

January

Achieving high standards in infection control

Date: 25 January 2008

Venue: BDA, London

www.bda.org/events

February

Preparing for retirement

Date: 1 February 2008

Venue: Aldwark Manor Hotel, York

www.bda.org/events

Utah Dental Association Convention

Date: 14-15 February 2008

Venue: Salt Lake City, USA

www.uda.org

\section{$B D J$ and BDA appoint new scientific advisor}

Professor Damien Walmsley has been appointed as the new joint $B D J$ and BDA Scientific Advisor. Formerly two posts, the newly combined position has been created to ensure the continuity of scientific advice and knowledge through the Association and the Journal.

Professor Walmsley, Professor of Restorative Dentistry at the School of Dentistry at the University of Birmingham, took up his appointment after ratification by the BDA's Representative Body.

'Damien's knowledge and experience will be a great asset to the Journal and we welcome him at a time of significant scientific and publishing change,' said BDJ Editor-in-Chief Stephen Hancocks. Professor Walmsley expressed delight at the appointment and determination to steer the Association and the Journal to the highest scientific standards.

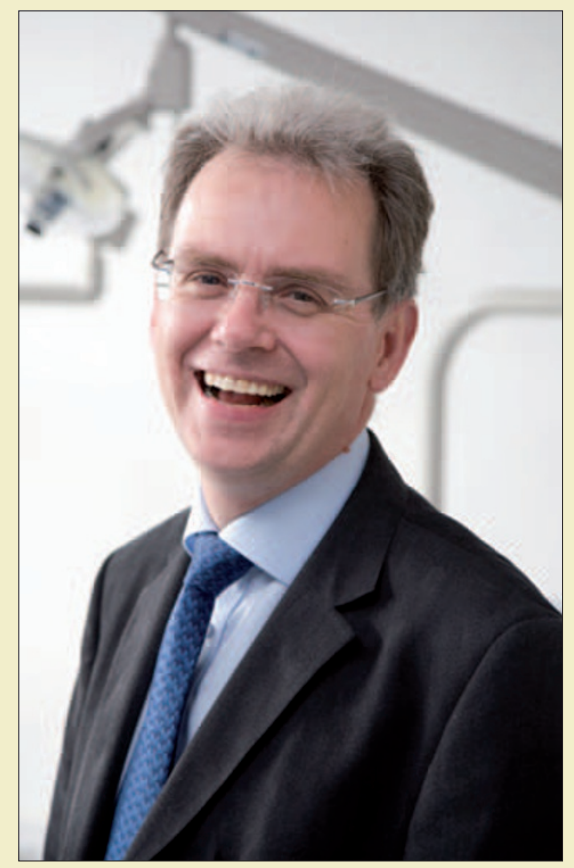

\section{New regulatory body created by the Department of Health}

The Department of Health has announced the creation of the Care Quality Commission which will regulate health including dentistry and social care by merging the majority of the functions of the Commission for Social Care Inspection, the Healthcare Commission and the Mental Health Act Commission.

Its creation is the Government's formal response to the November 2006 consultation document The future regulation of health and adult social care in England. It received over 100 responses from interested organisations, including the BDA, to its consultation and a Bill will be introduced in the next session of Parliament accompanied by a partial impact assessment (including an equality impact assessment) analysing the costs and benefits of these proposals. Subject to the passage of this legislation, the new commission will be established in 2008.

The new Care Quality Commission will be able to take action against any registered organisation, including dental practices, which puts patients or users of services at risk and will have the power to inspect, undertake investigations, issue warning notices, fine providers and even close down services.

The detail and scope of how the regulatory body will affect dentists has yet to be worked out, including whether its remit will extend to dentists who provide treatment solely on a private basis. This will be decided following discussions with the BDA and the GDC over the winter.

\section{Warfarin editorial acknowledgment}

We would like to acknowledge the help and advice of the following in the Editorial in the issue of 13 October 2007, Managing patients on warfarin: $\mathrm{Dr}$ David J Perry, Consultant Haematologist, Addenbrookes Hospital; Dr Tim J
C Noakes, Consultant Haematologist, Derriford Hospital NHS Trust; Dr Paul S Helliwell, National Patient Safety Agency, London.

We apologise that this was omitted at the time of publication. 